\title{
PENINGKATAN HASIL BELAJAR SISWA PADA MATERI HAK DAN KEWAJIBAN MASYARAKAT SEBAGAI WARGA NEGARA KELAS VB MIN 2 BANTUL SEMESTER II TAHUN PELAJARAN 2019/2020 MELALUI MODEL PEMBELAJARAN PROBLEM BASED LEARNING
}

\author{
Penulis \\ Noor Biatun \\ Guru MIN 2 Bantul Jogyakarta \\ noorbiatun@gmail.com
}

\begin{abstract}
ABSTRAK
Penelitian ini bertujuan untuk mengetahui apakah penggunaan model pembelajaran problem based larning dapat meningkatkan hasil belajar siswa kelas Vb MIN 2 Bantul pada materi hak dan kewajiban sebagai warga Negara. Penelitian ini merupakan Penelitian Tindakan Kelas. Subyek penelitian ini adalah Siswa Kelas Vb MIN 2 Kabupaten Bantul. Pengambilan data dilakukan dengan melaksanakan pembelajaran dalam dua siklus.

Analisis data dilakukan dengan menganalisis hasil evaluasi pembelajaran pada siklus 1 dan siklus II. Hasil penelitian menunjukkan bahwa terjadi peningkatan prestasi belajar materi hak dan kewajiban sebagai warga negara pada Siswa Kelas Vb MIN 2 Bantul. Sebelum dilaksanakna penelitian, diadakan evaluasi pada materi hak dan kewajiban warga negara, sebagai studi pendahuluan. Dari hasil evaluasi pendahuluan diperoleh nilai rata-rata kelas 72,22 atau $27 \%$ siswa telah memenuhi KKM yang ditetapkan. KKM yang ditetapkan adalah 75,00 . Hasil evaluasi pelaksanaan pembelajaran pada siklus 1, nilai rata-rata siswa mencapai 72,1. Dari 30 siswa, 16 siswa telah memenuhi KKM dan prosentasenya $53,34 \%$.

Adapun yang belum memenuhi KKM ada 14 anak dan prosentasenya 46,66 \%. Hasil evaluasi pada pelaksanaan pembelajaran siklus II, nilai rata-rata siswa mencapai 83,33. Dari 30 siswa 27 siswa telah memenuhi KKM dan prosentasenya $90 \%$, adapun siswa yang belum memenuhi KKM sebanyak 3 dan prosentasenya $10 \%$. Target keberhasilan pembelajaran kelas adalah nilai ratarata 75,00 dan sudah memenuhi KKM $80 \%$. Berarti bisa dikatakan keberhasilan penelitian telah tercapai.
\end{abstract}

Kata Kunci: Prestasi Belajar, Problem Based Learning

JORNAL PROGDI PPKn, FKIP UNIVET BANTARA SUKOHARJO BEKERJA SAMA DENGANASSOSIASI PROFESI PENDIDIKAN PANCASILA DAN KEWARGANEGARAAN (AP3KNI) JAWA TENGAH 
CIVICS EDUCATION AND SOCIAL SCIENSE JOURNAL(CESSJ)

Volume 2 Nomor 2 Edisi Bulan Desember 2020

\title{
IMPROVEMENT OF STUDENT LEARNING OUTCOMES IN THE RIGHTS AND OBLIGATIONS OF THE COMMUNITY AS CITIZENS OF CLASS VB MIN 2 BANTUL SEMESTER II OF THE STUDY YEAR 2019/2020 THROUGH THE LEARNING MODEL PROBLEM BASED LEARNING
}

\author{
Author \\ Noor Biatun Teacher of MIN 2 Bantul, Yogyakarta \\ noorbiatun@gmail.com
}

\begin{abstract}
The Increaseof Student Learning Outcomes on the Rights and Obligations of Society as Citizens of Class VB MIN 2 Bantul Semester II Academic Year 2019/2020 through Problem-Based LearningModel. This study aims to know whether the use of problem-based learningmodels can improve student learning outcomes in class VB MIN 2 Bantul on the subject of rights and obligations as citizens.

This research is a Classroom Action Research. The subjects of this study were students of class VB MIN 2 Bantul Regency. The data were collected by conducting learning in two cycles. The data analysis was carried out by analyzing the results of the learning evaluation in cycle I and cycle II. The results showed that the increase of learning outcome in the subject matter of rights and obligations as citizens of Class Vb MIN 2 Bantul. Before the research was carried out, an evaluation was conducted on the subject of rights and obligations of citizens as a preliminary study. From the results of the preliminary evaluation, it was found that the average class score was 72,22 and $27 \%$ of the 30 students had fulfilled the set Minimum Passing Criteria (MPC). The MPC was set on 75,00. The results of the learning cycle I evaluation showed that the students' average score reached 72,10 .

A total of 16 students have fulfilled the MPC or the percentage is $53,34 \%$, while those who had not fulfilled the MPC were $46,66 \%$ or 14 students. The results of the learning cycle II evaluation showed that the students' average score reached 83,33. As many as 27 students had met the MPC or the percentage was $90 \%$, while those who had not fulfilled the MPC were $10 \%$ or 3 students. The target of success in class learning is an average value of 75,00 and has met the MPC $80 \%$. These results indicated thatthe research success had been achieved
\end{abstract}

Keywords: Learning Achievement, Problem-Based Learning

JORNAL PROGDI PPKn, FKIP UNIVET BANTARA SUKOHARJO BEKERJA SAMA DENGANASSOSIASI PROFESI PENDIDIKAN PANCASILA DAN KEWARGANEGARAAN (AP3KNI) JAWA TENGAH 
CIVICS EDUCATION AND SOCIAL SCIENSE JOURNAL(CESSJ)

Volume 2 Nomor 2 Edisi Bulan Desember 2020

\section{PENDAHULUAN}

Pada proses pembelajaran di kelas 5B MIN 2 Bantul diperoleh data sebagai berikut: siswa kurang konsentrasi karena berbagai keadaan lingkungan sekolah yang kurang mendukung. Motivasi rendah, karena kurangnya dukungan dari masyarakat dan keluarga. Hasil prestasipun belum seluruhnya di atas KKM (di atas KKM hanya $27 \%$ ). PR maupun tugas yang diberikan siswa kadang tidak terselesaikan karena tidak adanya bimbingan dan pendamping dari orang tua. Kerjasama dengan temanpun hanya mungkin dilakukan pada siang hari atau libur sekolah.

Guru juga belum menggunakan alat pembelajaran secara maksimal, metode kurang bervariasi, sumber belajar masih sedikit, dan belum menggali kreatifitas siswa secara maksimal. Pembelajaran guru yang masih teacher center yang menjadikan siswa kurang aktif dan mandiri.

Materi tentang hak dan kewajiban sebagai warga Negara merupakan materi yang global yang memerlukan pemahaman secara rinci. Bagi siswa kelas VB MIN 2 Bantul hal ini merupakan kesulitan tersendiri yang harus memahami berbagai pasal dan bab yang berkaitan dengan hak dan kewajiban. Selain itu, pada materi ini merupakan materi baru yang dikenalkan siswa di kelas v.

Siswa MIN 2 Bantul kelas Vb ada 30 anak. Mereka, anak-anak dengan tipe aktif dan dinamis. Dalam pembelajaran, metode ceramah kurang efektif, maka guru harus menggunakan model pembelajaran yang aktif dan membuat anak bisa belajar sambil bermain. Selain itu pembelajaran menjadi lebih menyenangkan.

Kemampuan anak yang tidak sama, juga merupakan kendala dalam menyampaikan pembelajaran. Ketika pembelajaran berlangsung, anak yang kemampuannya di atas raa-rata tentu lebih cepat. Sedangkan yang di bawah ratarata sangat lambat menyelesaikan tugas. Sehingga penyelesaikan tugas dengan waktu yang sama sangat berbeda. Adanya perbedaan kemampuan ini menjadikan kelas kurang kondusif.

Hak dan kewajiban merupakan materi urgen sebagai bagian dari Mata pelajaran PPKN. Nilai PPKN tentu harus memenuhi KKM bila anak akan naik kelas. Hal itu menjadikan pembelajaran PPKN menjadi pembelajaran yang penting dan masuk dalam pembelajaran utama setelah Pendidikan Agama Islam.

Siswa sebagi bagian dari masyarakat Indonesia harus diajarkan tentang materi hak dan kewajiban masyarakat. Hal ini diharapkan agar anak-anak sadar hukum sejak dini. Seseorang yang sadar hukum, tentu akan mudah menempatkan dirinya baik sebagai pribadi, masyarakat, maupun sebagai rakyat dari sebuah bangsa dan negara.

Model pembelajaran Problem based learning, memberikan pengalaman kepada anak untuk menemukan dan bekerja secara kelompok dalam membahas suatu persoalan. Hal itu sesuai dengan model pembelajaran di era abad 21 sehingga pembelajaran berpusat pada siswa (student center). Siswa akan menemukan sendiri materi yang diajarkan disesuaikan dengan permasalahan dalam kehidupan sehari-hari. 
Diharapkan melalui pembelajaran problem based learning, anak dapat belajar sesuai dengan prinsip $4 \mathrm{c}$ yaitu communication, collaboration, critical thinking dan problem solving, serta creative innovative. Anak akan dapat bekerjasama dengan teman, peka terhadap suatu masalah, dapat memberikan solusi terhadap permasalahan yang ada tidak hanya mencela dan menghujat, dan anak lebih kreatif inovatif.

Dari beberapa permasalahan yang ada diambil rumusan masalah yang menjadi pembahasan pada penelitian ini: 1 . Apakah model pembelajaran problem based learning dapat meningkatkan hasil belajar siswa pada materi hak dan kewajiban masyarakat sebagai warga negara di kelas Vb MIN 2 Bantul Semester II Tahun Pelajaran 2019/2020? 2. Bagaimana penerapan model pembelajaran problem based learning dapat meningkatkan prestasi siswa pada materi hak dan kewajiban masyarakat sebagai warga negara di kelas Vb MIN 2 Bantul Semester II Tahun Pelajaran 2019/2020? Penelitian Tindakan Kelas dilakukan dengan tujuan untuk membahas: 1. Apakah model pembelajaran problem based learning dapat meningkatkan keaktifan siswa pada materi hak dan kewajiban masyarakat sebagai warga negara di kelas Vb MIN 2 Bantul. 2. Apakah model pembelajaran problem based learning dapat meningkatkan prestasi

\section{Kajian Teori}

\section{Hak dan Kewajiban Masyarakat Sebagai Warga Negara}

Pengertian hak adalah kuasa untuk menerima atau melakukan sesuatu yang semestinya diterima atau dilakukan oleh pihak tertentu dan tidak dapat oleh pihak lain manapun juga(Wahyu Widodo: 2015). Namun yang dimaksud disini adalah tindakan yang bersifat legal dan tidak menyalahi dari undang-undang yang berlaku. Yaitu UUD 1945 dan pancasila.

Sedangkan kewajiban adalah sesuatu yang harus kita lakukan dengan penuh rasa tanggung jawab (Wahyu Widodo: 2015). Hak dalam kehidupan bernegara dikatakan sebagai sesuatu yang seharusnya dimiliki oleh warga negara. Bersifat mutlak dan terdapat kebebasan didalamnya. Dalam kehidupan bernegara, setiap warga wajib memperoleh hak yang sesuai dengan yang diatur dalam perundangan berlaku. Namun dengan catatan bahwa warga negara juga dibebankan dengan menjalani kewajiban yang ditetapkan.

Kewajiban sebagai warga negara adalah semua hal yang harus dilakukan untuk memperoleh hak dari negara tempat tinggal. Pelaksanaan dari penjabaran pengertian hak dan kewajiban akan menciptakan kehidupan berbangsa dan bernegara yang teratur dan berimbang.

Dalam pengertian hak dan kewajiban berbangsa dan bernegara, dijelaskan bagaimana setiap penduduk diatur untuk bertingkah laku. Pengaturan tersebut menjadi penting agak tidak terjadi ketimpangan yang berarti mengenai pelaksanaan kewajiban dengan tuntutan hak yang diminta. 
CIVICS EDUCATION AND SOCIAL SCIENSE JOURNAL(CESSJ)

Volume 2 Nomor 2 Edisi Bulan Desember 2020

\section{Hasil Belajar}

Dalam Kamus Besar Bahasa Indonesia, hasil belajar diartikan hasil yang telah dicapai (dari yang telah dilakukan, dikerjakan dan sebagainya). Sedangkan Prestasi Belajar adalah penguasaan pengetahuan atau ketrampilan yang dikembangkan oleh mata pelajaran, lazimnya ditunjukkan dengan nilai tes atau angka nilai yang diberikan oleh guru. (Kamus Besar Bahasa Indonesia, 1995: 787).

Prestasi belajar (hasil belajar) menurut Nurkancana dan Sumartana (dalam Yoga,2009:2) adalah hasil yang dicapai oleh individu setelah mengalami proses belajar dalam jangka waktu tertentu. Selanjutnya menurut Nasution (dalam Ridwan, 2009: 1) prestasi belajar adalah kemampuan yang dicapai seseorang dalam berpikir, merasa, dan berbuat. Prestasi belajar sempurna apabila memenuhi tiga aspek yaitu: kognitif, afektif, dan psikomotor .

Menurut Purwanto (2016: 46) hasil belajar merupakan adanya suatu aktivitas atau proses yang mengakibatkan berubahnya input secara fungsional. Hasil belajar adalah perolehan dari proses belajar siswa sesuai dengan tujuan pengajaran. Prestasi adalah segala sesuatu yang telah dapat diciptakan melalui keuletan kerja dan akan memberikan perasaan senang.

Sedangkan Doni Juni Priansa memberikan pengertian bahwa hasil belajar adalah sesuatu yang dicapai atau diperoleh peserta didik berkat adanya usaha atau pikiran yang dinyatakan dalam bentuk penguasaan, pengetahuan, dan kecakapan dasar yang terdapat dalam berbagai aspek kehidupan sehingga tampak perubahan tingkah laku pada diri individu (Doni Juni: 2017).

Dari pengertian di atas dapat disimpulkan bahwa hasil belajar adalah hasil dari kegiatan belajar yang telah dicapai oleh siswa baik berupa kognitif (pengetahuan), afektif ( sikap), dan psikomotor (ketrampilan) yang ditunjukkan dengan nilai angka ataupun huruf yang diberikan oleh guru. Selanjutnya dari hasil belajar, akan tampak adanya perubahan tingkah laku.

Ciri-ciri keberhasilan belajar anak dapat ditinjau dari berbagai aspek: Dari perolehan nilai hasil belajar yaitu Siswa yang mendapatkan nilai hasil belajar di atas KKM, dapat dikategorikan sebagai keberhasilan dalam belajar. Tentu saja nilai itu diharapkan ada kenaikan pada setiap tahap. Baik dalam nilai ulangan harian, Ulangan Tengah Semester, dan Ulangan Semester. Dari segi psikologis yaitu Mengacu pada pengertian belajar bahwa belajar adalah proses perubahan tingkah laku yang dilakukan secara sadar, kontinu, fungsional, positif, aktif, permanen, dan terarah. Maka secara psikologis perubahan tingkah laku yang diperoleh anak didik hendaklah tertanam dalam hatinya dalam jangka lama, dapat digunakan dalam kehidupan sehari-hari, dan perubahan kearah yang lebih baik. Ciri-ciri siswa yang berhasil dalam belajarnya maka tingkah lakunya akan berubah dari tidak tahu menjadi tahu, tidak trampil menjadi trampil dan seterusnya. Perubahan itu akan tertanam terus dalam hatinya sehingga akan berguna dalam kehidupannya kelak. Tentu saja perubahan itu menuju ke arah yang lebih baik dan tidak bersifat sementara, namun selalu melekat dan akan diingat terus. 
Berdasar pendapat di atas dapat disimpulkan bahwa ciri-ciri keberhasilan belajar yaitu anak didik mengalami perubahan ke arah yang lebih baik, perubahan itu bersifat permanen (tahan lama), bermakna dan dapat dipergunakan dalam kehidupan sehari-hari.

Faktor-faktor yang mempengaruhi prestasi belajar dapat digolongkan ke dalam dua golongan yaitu faktor intern yang bersumber pada diri siswa dan faktor ekstern yang bersumber dari luar diri siswa. Pengaruh yang berasal dari diri sendiri (faktor intern) Faktor intern meliputi; kecerdasan atau intelegensi, perhatian, bakat, minat, motivasi, kematangan, kesiapan dan kelelahan. Sedangkan faktor ekstern terdiri dari lingkungan keluarga, lingkungan sekolah, dan lingkungan masyarakat (Menurut Slameto: 2003)

Menurut Mudzakir dan Sutrisno mengemukakan faktor-faktor yang mempengaruhi prestasi belajar yaitu: Faktor internal (faktor dari dalam diri manusia) Faktor fisiologi (yang bersifat fisik) Sakit, cacat tubuh, Faktor psikologi (faktor yang bersifat rohani) meliputi: Intelegensi, Bakat, Minat, Motivasi, Faktor Kesehatan Mental, Faktor Eksternal, Lingkungan keluarga mencakup : Perhatian orang tua, Keadaan ekonomi orang tua, Hubungan antara anggota keluarga. Lingkungan sekolah mencakup: Guru, Faktor alat, Kondisi gedung. Faktor mass media dan lingkungan sosial (masyarakat). Dan Lingkungan sosial

Jadi, dari pendapat di atas dapat disimpulkan bahwa prestasi belajar seseorang atau hasil akhir yang dicapai seseorang melalui kegiatan belajar dipengaruhi oleh berbagai hal, yaitu pengaruh dari dalam diri seseorang (internal) dan pengaruh dari luar diri seseorang (eksternal). Adapun yang menjadi faktor internal dalam penelitian ini adalah motivasi sedangkan faktor eksternal yang dapat mempengaruhi prestasi belajar siswa adalah sekolah dan lingkungan sekitar anak.

Mengukur hasil belajar artinya mengukur penguasaan siswa terhadap materi yang diajarkan oleh guru atau dipelajari oleh siswa. Ada beberapa alat ukur yang dapat digunakan dalam mengukur hasil belajar siswa baik kognitif, afektif, maupun psikomotorik.

Ciri-ciri keberhasilan belajar anak dapat ditinjau dari berbagai aspek: Dari perolehan nilai hasil belajar Siswa yang mendapatkan nilai hasil belajar di atas KKM, dapat dikategorikan sebagai keberhasilan dalam belajar. Tentu saja nilai itu diharapkan ada kenaikan pada setiap tahap. Baik dalam nilai ulangan harian, Ulangan Tengah Semester, dan Ulangan Semester. Dari segi psikologis Mengacu pada pengertian belajar bahwa belajar adalah proses perubahan tingkah laku yang dilakukan secara sadar, kontinu, fungsional, positif, aktif, permanen, dan terarah. Maka secara psikologis perubahan tingkah laku yang diperoleh anak didik hendaklah tertanam dalam hatinya dalam jangka lama, dapat digunakan dalam kehidupan sehari-hari, dan perubahan kearah yang lebih baik.

Ciri-ciri siswa yang berhasil dalam belajarnya maka tingkah lakunya akan berubah dari tidak tahu menjadi tahu, tidak trampil menjadi trampil dan seterusnya. Perubahan itu akan tertanam terus dalam hatinya sehingga akan 
berguna dalam kehidupannya kelak. Tentu saja perubahan itu menuju ke arah yang lebih baik dan tidak bersifat sementara, namun selalu melekat dan akan diingat terus. Menurut Rahman Abror belajar yaitu menimbulkan perubahan yang relatif tetap, perubahan itu membedakan antara keadaan sebelum individu berada dalam situasi belajar dan sesudah belajar, perubahan itu dilakukan lewat kegiatan yang disengaja atau diperkuat.

Berdasar pendapat di atas dapat disimpulkan bahwa ciri-ciri keberhasilan belajar yaitu anak didik mengalami perubahan ke arah yang lebih baik, perubahan itu bersifat permanen (tahan lama), bermakna dan dapat dipergunakan dalam kehidupan sehari-hari.

\section{Model Pembelajaran Problem Based Learning (model pembelajaran)}

Model pembelajaran adalah suatu perencanaan atau suatu pola yang digunakan sebagai pedoman dalam merencanakan pembelajaran dikelas atau pembelajaran dalam tutorial.( Trianto: 2012) Model pembelajaran problem based learning merupakan rangkaian aktivitas pembelajaran artinya dalam implementasi proses belajar ada sejumlah kegiatan yang harus dilakukan siswa. Siswa tidak hanya mendengar, mencatat, kemudian menghafal materi pelajaran, tetapi melalui model problem based learning (PBL) siswa menjadi aktif berpikir, berkomunikasi, mencari dan mengolah data, dan akhirnya membuat kesimpulan. Model pembelajaran PBL merupakan pembelajaran inovatif yang berpusat pada peserta didik ( student centered) dan menetapkan guru sebagai motivator dan fasilitator, dimana peserta didik diberi peluang bekerja secara otonom mengkontruksi belajarnya.( Trianto: 2014).

Berarti pada pembelajaran ini, anak belajar untuk menyelesaikan masalah nyata, sehingga anak bisa berpikir kritis dalam menghadapi masalah. Dalam pembelajaran ini anak diberi kebebasan untuk merencanakan aktivitas belajar, melaksanakan proyek secara kolaboratif, dan pada akhirnya menghasilkan produk kerja yang dapat dipresentasikan kepada orang lain.

Dari beberapa pendapat tersebut dapat disimpulkan bahwa model pembelajaran problem based learning adalah rangkaian aktivitas pembelajaran yang berpusat pada siswa, dengan memberikan masalah nyata sehingga anak belajar berfikir kritis, mempunyai ketrampilan memecahkan masalah, dan dapat melaksanakan tugas secara kolaboratif, komunikatif, dan kreatif.

Karakteristik Model Pembelajaran Problem Based Learning Model pembelajaran problem based learning memiliki 6 ciri yaitu: Kegiatan belajar mengajar diawali dengan pemberian masalah oleh guru. Permasalahan yang diberikan berkaitan dengan kehidupan nyata . Peserta didik bertanggung jawab untuk mendapatkan dan mengelola informasi yang dikumpulkan Melakukan evaluasi secara continue Peserta didik secara teratur melihat kembali apa yang mereka kerjakan, Hasil akhir berupa produk dan evaluasi kualitasnya, dan Kelas memiliki . atmosfer yang memberi toleransi kesalahan dan perubahan. 
Langkah-langkah Model Pembelajaran Problem Based Learning Model pembelajaran problem based learning memiliki tahapan sebagai berikut: Orientasi peserta didik terhadap masalah Pada tahap ini guru harus menjelaskan tujuan pembelajara, permasalahan yang dibahas, dan bagaimana guru mengevaluasi. Hal ini untuk memberi konsep dasar kepada peserta didik. Guru harus bisa memberi motivasi peserta didik agar aktif dalam pemecahan masalah. Mengorganisasikan peserta didik Guru membantu peserta didik mendefinisikan dan mengorganisasikan tugas belajar yang berhubungan dengan masalah yang telah diorientasi, seperti membentuk kelompok kecil, membaca masalah, dan membuat hipotesis. Membimbing penyelidikan individu dan kelompok. Guru mendorong peserta mengumpulkan informasi sebanyak-banyaknya, melaksanakan eksperimen, menciptakan dan membagikan ide mereka sendiri. Mengembangkan dan menyajikan hasil karya Guru membantu peserta didik dalam menganalisis data yang telah terkumpul, kemudian dikelompokkan berdasar kategorinya. Peserta memberi argumen terhadap pemecahan masalah. Menganalisis dan mengevaluasi proses pemecahan masalah Guru meminta peserta didik untuk merekonstruksi pemikiran dan aktivitas yang telah dilakukan selama proses kegiatan belajarnya. Guru dan peserta didik menganalisis dan mengevaluasi pemecahan masalah yang dipresentasikan.

Sedangkan menurut Dr. Kokom Komalasari, M.Pd.(2013: 59) membagi langkah-langkah pembelajaran Problem based learning menjadi 5: Gur menjelaskan kompetensi yang akan dicapai dan menyebutkan sarana atau alat pendukung yang dibutuhkan. Memotivasi siswa untuk terlibat dalam aktivitas pemecahan masalah yang dipilih. Guru membantu siswa mendefinisikan dan mengorganisasikan tugas belajar yang berhubungan dengan masalah tersebut (menetapkan topic, tugas, jadwal, dll) Guru mendorong siswa untuk mengumpulkan informasi yang sesuai, eksperimen untuk mendapatkan penjelasan dan pemecahan masalah, pengumpulan data, hipotesis, pemecahan masalah. Guru membantu siswa dalam merencanakan menyiapkan karya yang sesuai seperti laporan dan membantu mereka berbagi tugas dengan temannya. Guru membantu siswa untuk melakukan refleksi atau evaluasi terhadap eksperimen mereka dan proses-proses yang mereka gunakan.

Dari berbagai pendapat tersebut, dapat disimpulkan bahwa langkahlangkah pembelajaran problem based learning dapat dilakukan dengan 5 tahapan yaitu: Menjelaskan kompetensi, membantu siswa mendefinisikan dan mengorganisasikan, mendorong siswa mengumpulkan informasi, membantu siswa menyiapkan karya, dan melakukan refleksi atau evaluasi.

Tujuan Model Pembelajaran Problem Based Learning Menurut Rohman (2011: 189) mengemukakan bahwa terdapat beberapa tujuan dari pembelajaran problem based learning: Untuk mendorong kerjasama penyelesaian tugas antar siswa. Memiliki elemen-elemen belajar mengajar sehingga mendorong tingkah laku pengamatan siswa dan dialog dengan lainnya. Melibatkan siswa dan menyelidiki pilihan sendiri yang 
memungkinkan mereka memahami dan menjelaskan fenomena dunia nyata. Melibatkan ranah (kognitif, afektif, dan psikomotorik) pada siswa secara seimbang sehingga hasilnya bisa lebih lama diingat oleh siswa. Dapat membangun optimisme siswa bahwa masalah adalah sesuatu yang menarik untuk dipecahkan bukan suatu yang harus dihindari.

\section{Hipotesis Tindakan}

Dari rumusan permasalahan yang ada dapat dirumuskan hipotesis "Dengan melalui model pembelajaran problem based learning ternyata dapat meningkatkan hasil belajar siswa kelas v MIN 2 Bantul semester II tahun pelajaran 2019/2020 pada materi hak dan kewajiban warga Negara “

\section{METODE}

Penelitian dilaksanakan di kelas Vb MIN 2 Bantul dengan jumlah siswa 30 anak, terdiri dari 17 anak laki-laki dan 13 anak perempuan. Kemampuan anak kelas $\mathrm{Vb}$ beragam. Ada 3 anak $(10 \%)$ yang kurang dapat memahami bacaan. Sebagian lancar membaca ada 18 anak ( $60 \%$ ) dan 9 anak (30\%) sangat lancar membaca. Dengan keadan yang seperti itu maka diperlukan metode dan model pembelajaran yang dapat membantu anak untuk memahami materi dengan baik. Dalam pembelajaran materi hak dan kewajiban warga Negara dan umumnya sub mata pelajaran PKN, siswa kelas Vb MIN 2 Bantul nilainya masih rendah. Dari 30 anak, yang mendapat nilai di bawah KKM (belum tuntas) ada 22 anak ( $73 \%$ ), dan sudah tuntas $((=/ \nVdash K M)$ ada 8 anak ( $27 \%)$. Hal itu menunjukkan bahwa materi pembelajaran hak dan kewajiban umumnya materi PPKN sangat perlu ditingkatkan sehingga anak dapat mencapai nilai KKM minimal bahkan di atas KKM. Adapun KKM yang ditetapkan adalah 75.

\section{Prosedur Penelitian}

\section{Siklus 1}

\section{a) Perencanaan tindakan (Plan) siklus}

Dalam perencanaan, peneliti melakukan beberapa hal yaitu: Merencanakan program pembelajaran yang akan dilaksanakan dalam proses belajar mengajar dengan membuat RPP lengkap dengan evaluasinya. Menentukan pokok bahasan, dalam hal ini pokok bahasan tentang materi hak dan kewajiban warga Negara. Mengembangkan skenario pembelajaran, pembelajaran yang dilaksanakan menggunakan model pembelajaran problem based learning dengan media gambar. Siswa dikelompokkan dalam mengerjakan LKS. Menyusun LKS/ media, LKS menggunakan soal uraian dan media yang digunakan adalah media gambar. Menyiapkan sumber belajar, sumber belajar berasal dari buku, internet, siswa, lingkungan, dan gambar. Mengembangkan format evaluasi. Evaluasi dilaksanakan menggunakan tes dan non tes. Mengembangkan format observasi pembelajaran. Menyediakan sarana prasarana, dan hal lain yang diperlukan. 
Dalam hal ini sarana yang disiapkan adalah laptop, LCD, media gambar, dan lingkungan.

\section{b) Pelaksanaan tindakan (Action) siklus1}

Melaksanakan pembelajaran sesuai rencana tindakan yang telah disusun untuk siklus 1 yaitu hari selasa, 4 Maret 2020. Pada kegiatan inti siswa dikelompokkan menjadi 6 kelompok. Masing-masing kelompok diberikan LK yang berbeda berkaitan dengan persoalan hak, kewajiban, dan tanggung jawab sebagai warga masyarakat.

Masing-masing kelompok diberikan gambar berkaitan dengan hak yang harus diperoleh warga Negara: Kelompok 1 hak warga Negara memiliki kedudukan yang sama di mata hukum dan di dalam pemerintahan (pasal 27 ayat 1), Kelompok 2 hak warga Negara atas pekerjaan dan penghidupan yang layak (pasal 27 ayat 2). Kelompok 3 hak warga Negara dalam memperoleh pendidikan dan pengajaran ( pasal 31 ayat 1). Kelompok 4 hak warga Negara untuk berserikat dan berkumpul dan mengeluarkan pendapat (pasal 28 ) Kelompok 5 hak warga Negara bebas untuk memilih, memeluk, dan menjalankan agama dan kepercayaan masing-masing yang dipercayai (pasal 29 ayat 2 ).

Setelah masing- masing kelompok mengerjakan LK, lalu dipresentasikan dan kelompok lain memberi saran ataupun menambah. Pada akhir pembelajaran, hasil kerja kelompok ditempelkan. Guru memberikan penguatan dan siswa diminta untuk mengamati pekerjaan kelompok lain. Guru memberikan refleksi/ umpan balik terhadap pembelajaran yang telah dilaksanakan.

\section{c) Pengamatan (Observe) siklus 1}

Pengamatan dilakukan terhadap guru dan siswa. Dalam proses tindakan 1 pengamatan yang seksama dan berpusat pada masalah penelitian. Yang dilakukan dalam proses pengamatan adalah: Mengamati kegiatan siswa dalam pembelajaran. Mengamati kegiataan siswa dalam mempresentasikan hasil kerja kelompok. Melakukan penilaian. Menghitung presentase hasil belajar.

\section{d) Diskusi refleksi siklus 11}

Hal-hal yang dilakukan dalam tahap ini adalah: Mengidentifikasi kesulitan dan hambatan pembelajaran pada siklus 1. Memperbaiki tindakan berdasar kesulitan dan hambatan yang ditemukan dan pengolahan nilai.

\section{Siklus 2}

\section{a) Perencanaan tindakan (Plan) siklus 2}

Seperti dalam perencanaan siklus 1 , peneliti melakukan beberapa hal yaitu: Merencanakan program pembelajaran yang akan dilaksanakan dalam proses belajar mengajar dengan membuat RPP lengkap dengan evaluasinya. 
Menentukan pokok bahasan, dalam hal ini pokok bahasan tentang materi hak dan kewajiban warga Negara. Mengembangkan skenario pembelajaran, pembelajaran yang dilaksanakan menggunakan model pembelajaran problem based learning dengan media gambar. Siswa dikelompokkan dalam mengerjakan LKS. Menyusun LKS/ media, LKS menggunakan soal uraian dan media yang digunakan adalah media gambar. Menyiapkan sumber belajar, sumber belajar berasal dari buku, internet, siswa, lingkungan, dan gambar. Mengembangkan format evaluasi. Evaluasi dilaksanakan menggunakan tes dan non tes. Tes digunakan untuk mengetahui hasil belajar siswa, sedangkan non tes digunakan untuk mengetahui keaktifan siswa dan partisipasi siswa dalam kelompok. Mengembangkan format observasi pembelajaran. Observasi dilaksanakan terhadap siswa dan guru. Siswa dan guru akan diamati oleh observer yang menggandeng guru lain untuk menjadi pengamat. Menyediakan sarana prasarana, dan hal lain yang diperlukan. Dalam hal ini sarana yang disiapkan adalah laptop, LCD, media gambar, dan lingkungan.

\section{b) Pelaksanaan tindakan (Action) siklus2}

Melaksanakan pembelajaran sesuai rencana tindakan yang telah disusun untuk siklus1. Pada kegiatan inti siswa dikelompokkan menjadi 6 kelompok yang berbeda dengan kelompok sebelumnya. Masing-masing kelompok diberikan LK yang berbeda berkaitan dengan persoalan hak, kewajiban, dan tanggung jawab sebagai warga masyarakat. Masing-masing kelompok diberikan gambar berkaitan dengan kewajiban yang harus diperoleh warga Negara: Kelompok 1 kewajiban membayar pajak dan retribusi yang telah ditetapkan oleh pemerintah pusat dan pemerintah daerah (pemda) (pasal 23A) Kelompok 2 kewajiban warga Negara menaati serta menjunjung tinggi dasar Negara, hukum, dan pemerintahan tanpa terkecuali, serta dijalankan dengan sebaik-baiknya. (pasal 27 ayat 1) Kelompok 3 kewajiban warga Negara untuk berperan serta dalam membela, mempertahankan kedaulatan Negara Indonesia dari serangan musuh. (pasal 30 ayat 1) Kelompok 4 kewajiban warga Negara untuk menghormati hak azazi orang lain dan menjunjung tinggi moral, nilai agama, keamanan, dan ketertiban umum. Kelompok 5 kewajiban warga Negara untuk mengikuti pendidikan dasar yang sepenuhnya dibiayai oleh Negara.

Setelah masing- masing kelompok mengerjakan LK, lalu dipresentasikan dan kelompok lain memberi saran ataupun menambah. Pada akhir pembelajaran, hasil kerja kelompok ditempelkan. Guru memberikan penguatan dan siswa diminta untuk mengamati pekerjaan kelompok lain. Guru memberikan refleksi/ umpan balik terhadap pembelajaran yang telah dilaksanakan. 
CIVICS EDUCATION AND SOCIAL SCIENSE JOURNAL(CESSJ)

Volume 2 Nomor 2 Edisi Bulan Desember 2020

\section{c) Pengamatan (Observe) siklus 2}

Pengamatan dilakukan terhadap guru dan siswa. Dalam proses tindakan 1 pengamatan yang seksama dan berpusat pada masalah penelitian. Pengamatan dicatat dalam catatan lapangan dan lembar observasi. Untuk melakukan tindakan selanjutnya dilakukan diskusi dengan teman sejawat. Dalam siklus 2 observer dilakukan oleh 2 orang yaitu Ahmad Farid,M.Pd dan Suwiatmi,S.Pd.SD. Yang dilakukan dalam proses pengamatan adalah: Mengamati kegiatan siswa dalam pembelajaran. Mengamati kegiataan siswa dalam mempresentasikan hasil kerja kelompok. Melakukan penilaian. Menghitung presentase hasil belajar. Diskusi refleksi siklus 2

Hasil observasi, catatan lapangan, dan hasil tes dikaji dan direnungkan kembali. Kemudian dilakukan evaluasi guna menyempurnakan tindakan berikutn. Hal-hal yang dilakukan dalam tahap ini adalah: Mengidentifikasi kesulitan dan hambatan pembelajaran pada siklus Memperbaiki tindakan berdasar kesulitan dan hambatan yang ditemukan dan pengolahan nilai.

Metode pengumpulan data pada penelitian ini adalah menggunakan metode observasi, angket, wawancara, dan tes. Dengan penjelasan sebagai berikut:

Observasi, Observasi digunakan untuk: memperoleh data tentang proses pelaksanaan tindakan yang menggunakan model pembelajaran problem based learning. Pada pelaksanaan tindakan ini peneliti dibantu oleh seorang observer teman sejawat Ahmad Farid, M.Pd. Untuk memperoleh data keaktifan siswa selama mengikuti pembelajaran. Pelaksanaan observasi peneliti dibantu oleh seorang guru sebagai observer dengan tujuan agar data yang diperoleh memiliki nilai validitas yang dapat dipertanggungjawabkan.

Tes. Tes digunakan untuk memperoleh data hasil belajar siswa. Tes yang digunakan adalah tes tertulis dengan soal pilihan ganda dan essay. Tes dilaksanakan setelah 3x pertemuan pada setiap siklus. Langkah-langkah tes tertulis sebagai berikut: Mengevaluasi hasil belajar berdasar indikator. Mempresentasekan keberhasilan, dengan membandingkan data hasil tes awal dengan hasil tes tindakan 1. Mengidentifikasi dan mencatat skor siswa pada lembar hasil belajar. Pada pelaksanaan mengolah skor tes tertulis menjadi nilai, menggunakan langkah-langkah sebagai berikut: Mengisi tabel hasil tes pada setiap kolom masing-masing siswa.Menentukan ketuntasan untuk masing-masing siswa

$$
\begin{aligned}
& \mathrm{N}=\underline{\mathrm{s}} \times \mathbf{n} 100 \\
& \mathrm{n}
\end{aligned}
$$

Menghitung jumlah nilai hasil tes untuk seluruh siswa. Dan Menghitung presentase hasil tes seluruh siswa dengan rumus

$$
\mathrm{H}=\frac{\sum \mathrm{N}}{\sum \mathrm{n}} \times 100 \%
$$


CIVICS EDUCATION AND SOCIAL SCIENSE JOURNAL(CESSJ)

Volume 2 Nomor 2 Edisi Bulan Desember 2020

$$
\begin{aligned}
& \text { Keterangan: } \\
& \mathrm{H}=\text { Presentase hasil tes } \\
& \mathrm{N}=\text { Jumlah nilai } \\
& \mathrm{n}=\text { Jumlah siswa }
\end{aligned}
$$

Menentukan peningkatan hasil belajar siswa serta Menyimpulkan temuan penelitian.

Tahapan yang dilakukan dalam analisis data yaitu: Klasifikasi data yaitu data diklasifikasi sesuai kelompok tertentu. Penyajian data yaitu dilakukan dengan menyusun sekumpulan informasi yang diperoleh dari observasi pelaksanaan pembelajaran. Menganalisis tingkat keberhasilan pembelajaran dengan membandingkan hasil belajar pada siklus I dan siklus II. Menyimpulkan data yang dilakukan setelah data diklasifikasi dan disajikan.

Data yang telah diperoleh dalam penelitian dianalisis sejak pengumpulan data sampai seluruh data terkumpul untuk mengetahui keberhasilan penelitian. Sedangkan teknik yang digunakan untuk analisis data pada penelitian ini adalah teknik deskriptif analitik dengan penjelasan sebagai berikut:

a. Data kuantitatif yang diperoleh dari hasil postes dan diolah menggunakan deskripsi presenatase. Nilai yang diperoleh siswa dikategorikan sebagai (1) belum tuntas (kurang dari KKM), (2) tuntas (sama atau lebih dari $\mathrm{KKM}$ ). KKM disini menggunakan KKM per KD. Karena KD yang digunakan pada kondisi awal siklus 1 dan seterusnya memiliki tingkat kesulitan yang berbeda. Dari rekapitulasi setiap siklus dilakukan prosentase, yaitu prosentase nilai siswa yang belum tuntas (di bawah KKM), dan prosentase nilai siswa yang sudah tuntas (sama atau lebih dari KKM). Dengan melihat kondisi awal, siklus 1, dan siklus 2 dapat diketahui apakah hasil belajar siswa mengalami peningkatan atau tidak. Dikatakan meningkat bila prosentase nilai siswa di atas KKM mengalami peningkatan.

b. Data kualitatif diperoleh dari observasi kegiatan guru dan kegiatan siswa sebagai dasar untuk mendikripsikan keberhasilan penerapan model pembelajaran problem based learning. Juga sebagai dasar untuk melakukan refleksi dan perbaikan pembelajaran setiap siklus. Perbaikan pembelajaran dikatakan berhasil, apabila ada peningkatan hasil belajar siswa dari siklus 1 ke siklus selanjutnya.

c. Data kualitatif yang diperoleh observasi ( satu observer) tentang keaktifan siswa selama pembelajaran digunakan untuk mendeskripsikan keberhasilan penerapan model problem based learning. Dikatakan berhasil apabila ada peningkatan dari kondisi awal ke siklus 1 dan siklus selanjutnya.

Indikator keberhasilan meliputi keberhasilan guru dalam mengajar, peningkatan keaktifan siswa dan keberhasilan siswa dalam mendapatkan nilai. Keberhasilan guru dalam mengajar didasarkan pada hasil observasi teman sejawat kemudian didiskusikan dan sebagai dasar untuk perbaikan pembelajaran selanjutnya. 
Indikator keberhasilan dari data kuantitatif yaitu hasil belajar siswa, dikatakan ada kenaikan apabila ada kenaikan prosentase nilai siswa di atas KKM setelah melaksanakan postes setiap akhir siklus. Keberhasilan proses belajar mengajar apabila siswa yang mendapat nilai di bawah KKM minimal $10 \%$. Sedangkan prosentase keberhasilan apabila nilai siswa yang mencapai KKM atau lebih minimal $80 \%$.

\section{HASIL PENELITIAN DAN PEMBAHASAN}

\section{A. Deskripsi Kondisi Awal}

Penelitian Tindakan Kelas ini dilaksanakan di kelas Vb MIN 2 Bantul. Jumlah keseluruhan siswa ada 30 siswa terdiri dari 17 siswa laki-laki dan 13 siswa perempuan. Kemampuan siswa dari tes sebelumnya dikatakan rataratanya masih rendah. Ada $73 \%$ siswa memperoleh nilai di bawah KKM, $27 \%$ siswa memperoleh nilai sama atau di atas KKM. KKM yang ditetapkan adalah 75. Kondisi awal pembelajaran tematik sub tema PPKn materi hak dan kewajiban warga Negara dapat digambarkan dalam tabel sebagai berikut:

\section{Tabel 4.1}

\section{Kondisi awal Hasil belajar siswa MIN 2 Bantul Sub tema PPKn materi hak dan kewajiban}

\begin{tabular}{|l|c|c|c|}
\hline \hline \multirow{2}{*}{ Hasil Belajar } & \multirow{2}{*}{ Kondisi Awal } & \multicolumn{2}{c|}{ Siklus } \\
\cline { 3 - 4 } & & Satu & Dua \\
\hline Tuntas =/ $\geq$ KKM & $27 \%$ & $46,66 \% \%$ & $85 \%$ \\
\hline Belum Tuntas: < KKM & $73 \%$ & $53 \%$ & $15 \%$ \\
\hline
\end{tabular}

\section{B. Deskripsi Hasil Penelitian}

\section{Siklus I}

\section{a. Perencanaan Tindakan Siklus I}

Rencana tndakan pada sklus 1 hal yang dilakukan untuk persiapan adalah membuat RPP untuk tiga kali pertemuan (RPP terlampir). RPP dikembankan dengan menggunakan model pembelajaran problem based learning sesuai langkah-langkah yang dibahas pada kajian teori. Kompetendi Dasar yang akan diajarkan dalam RPP adalah KD 1.2. Menghargai kewajiban, hak, dan tanggung jawab sebagai warga masyarakat dan umat beragama dalam kehidupan sehari-hari. KD 2.2. menunjukkan sikap tanggung jawab dalam memenuhi kewajiban dan hak sebagai warga masyarakat dalam kehidupan sehari-hari.. RPP ini akan diimplementasikan pada tiga kali pertemuan yaitu pertemuan pertama hari selasa, 3 Maret 2020, pertemuan kedua hari Jumat, 6 Maret 2020, dan pertemuan ketiga hari Selasa, 10 Maret 2020. 


\section{b. Pelaksanaan Tindakan Siklus I}

Berdasarkan hasil observasi yang dilakukan oleh tiga observer (teman sejawat) dengan menggunakan lembar observasi (terlampir) dalam tiga kali pertemuan, yaitu pertemuan pertama hari selasa, 3 Maret 2020, pertemuan kedua hari Jumat, 6 Maret 2020, dan pertemuan ketiga hari Selasa, 10 Maret 2020, ditemukan bahwa proses pembelajaran berlangsung sebagai berikut:

\section{1) Pertemuan pertama}

Secara umum pelaksanaan sudah sesuai rencana tindakan (RPP pertemuan 1. Berdasarkan observasi dan analisis data diketahui bahwa ada beberapa langkah pembelajaran yang tidak dilakukan secara optimal, yaitu: Guru belum sepenuhnya mengorganisir siswa, siswa hanya membuat kelompok sendiri sehingga kemampuan kelompok kurang merata Guru belum memberikan penilaian pada persiapan siswa ketika akan presentasi, sehingga penampilan siswa kurang maksimal. Guru belum mengelompokkan siswa dengan merata, Sehingga ada kelompok aktif sekali tetapi ada kelompok yang pasif, sehingga pembelajaran kurang hidup. Guru belum membantu siswa dalam membagi tugas, Sehingga dalam kelompok yang aktif hanya sebagian saja. Pengelompokkan belum merata, sehingga pembelajaran kurang hidup

\section{2) Pertemuan kedua}

Secara umum pelaksanaan pembelajaran pada pertemuan kedua sudah sesuai dengan rencana tindakan (RPP pertemuan kedua). Berdasarkan observasi diketahui bahwa ada beberapa langkah pembelajaran yang perlu diperbaiki. Namun secara keseluruhan sudah lebih baik dari pada pertemuan pertama. Adapun hal-hal yang perlu diperbaiki adalah: Pembentukan kelompok belum merata antara kemampuan siswanya. Guru belum memberikan motivasi yang optimal, sehingga siswa belum sepenuhnya belajar dengan semangat. Guru kurang memberikan apresiasi positif kepada penanmpilan siswa, sehingga siswa kurang termotivasi. Guru belum memberikan penjelasan yang detil tentang permasalahan yang diajukan, sehngga siswa masih kebingungan untuk menyampaikan solusi.

\section{3) Pertemuan ketiga}

Secara umum pembelajaran pada pertemuan ketiga sudah lebih baik dan sesuai dengan rencana yang dibuat (RPP pertemuan ketiga). Hanya masih ada kekurangan sedikit yang nanti diperbaiki pada pembelajaran siklus kedua. 
Hasil Penelitian Siklus I. Hasil Belajar Berdasarkan tes yan dilakukan di akhir siklus 1 diketahui bahwa rata-rata nilai yang diperoleh siswa untuk mata pelaj<aran tematik sub tema PPKn KD 3.2, dan 4.2 (KKM 75) adalah 71,2. Kalau dipresentase berdasarkan kategori belum tuntas $(<\mathrm{KKM})$ dan tuntas $(=/$ KKM $)$ adalah sebagai berikut: Persentase Belum Tuntas $14 / 30$ x $100 \%=46,66 \%$ Persentase Tuntas $16 / 30 \times 100 \%=53,34 \%$

Bla dibandingkan dengan hasil belajar siswa pada kondisi awal, hasil belajar pada siklus 1 mengalami peningkatan. Peningkatan dapat dilihat pada tabel sebagai berikut:

Tabel 4.2.

Nilai Siswa Kondisi Awal dan Siklus 1

\begin{tabular}{|c|c|c|c|c|}
\hline No. & Kategori Nilai & Kondisi Awal & Siklus 1 & $\overline{\text { Siklus } 2}$ \\
\hline 1. & $\begin{array}{l}\text { Persentase Belum } \\
\text { Tuntas }(<\mathrm{KKM})\end{array}$ & $73 \%$ & $46,66 \%$ & $10 \%$ \\
\hline 2. & $\begin{array}{ll}\text { Persentase } & \text { Tuntas } \\
(=/ \text { KKM }) & \end{array}$ & $27 \%$ & $53,34 \%$ & $90 \%$ \\
\hline
\end{tabular}

Dari tabel di atas menunjukkan bahwa hasil belajar siswa mengalami peningkatan setelah dilakukan tindakan. Presentase siswa yang belum tuntas mengalami penurunan dari kondisi awal $73 \%$ menjadi 46,66\% (pada siklus 1). Prsentase siswa yang sudah tuntas mengalami kenaikan dari kondisi awal $27 \%$ menjadi 53,34\% pada siklus 1 .

Indikator keberhasilan PTK adalah, PTK dikatakan sudah berhasil jika presentase siswa yang nilai hasil belajarnya sudah tuntas mencapai minimal $80 \%$. Dari tabel menunjukkan bahwa presentase siswa yang nilainya tuntas baru mencapai 53,34\%, maka PTK harus dilanjutkan pada siklus 2.

\section{c. Proses Pembelajaran}

Dari tiga observer menunjukkan bahwa pembelajaran secara umum sudah bagus, tetapi harus ada beberapa yang harus diperbaiki: Perlu variasi mengajar Dalam pembentukan kelompok perlu dilakukan kesepakatan antara guru dan murid Guru belum memberikan motivasi yang lebih untuk semakin menggugah semangat siswa.

\section{1) Refleksi Siklus 1}

Setelah mengkaji proses pembelajaran yang dilakukan pada siklus 1, bagaimana hasil belajar dan proses yang dilakukan guru, kemudian peneliti melakukan refleksi. Tujuannya untuk mendapatkan solusi perbaikan yang dapat dilakukan pada siklus 2 . Hasil dari kegiatan refleksi itu adalah sebagai berikut: Guru (peneliti) harus bisa mengembangkan variasi pembelajaran, Guru 
harus menggunakan berbagai model dalam pembentukan kelompok, 3) Guru (peneliti) harus lebih memberikan motivasi dan semangat kepada anak didik Guru (peneliti) secara umum harus mengoptimalkan siswa agar mendapatkan nilai yang lebih baik.

\section{Siklus II}

\section{a. Perencanaan Tindakan Siklus II}

Rencana tndakan pada sklus II hal yang dilakukan untuk persiapan adalah membuat RPP untuk tiga kali pertemuan (RPP terlampir). RPP dikembangkan dengan menggunakan model pembelajaran problem based learning sesuai langkah-langkah yang dibahas pada kajian teori. Kompetendi Dasar yang akan diajarkan dalam RPP adalah KD 3.2. memahami hak, kewajiban, dan tanggung jawab sebagai warga dalam kehidupan sehari-hari. KD 4.2. Menjelaskan hak, kewajiban, dan tanggung jawab sebagai warga masyarakat dalam kehidupan sehari-hari. RPP ini akan diimplementasikan pada tiga kali pertemuan yaitu pertemuan pertama hari Jumat, 13 Maret 2020, pertemuan kedua hari Selasa, 17 Maret 2020, dan pertemuan ketiga hari Kamis, 19 Maret 2020.

\section{b. Pelaksanaan Tindakan Siklus II}

Berdasarkan hasil observasi yang dilakukan oleh tiga observer (teman sejawat) dengan menggunakan lembar observasi (terlampir) dalam tiga kali pertemuan, yaitu pertemuan pertama hari Jumat, 13 Maret 2020, pertemuan kedua hari Selasa, 17 Maret 2020, dan pertemuan ketiga hari Kamis, 19 Maret 2020, ditemukan bahwa proses pembelajaran berlangsung sebagai berikut:

1) Pertemuan pertama

Secara umum pelaksanaan sudah sesuai rencana tindakan (RPP pertemuan 1. Berdasarkan observasi dan analisis data diketahui bahwa pembelajaran sudah berlangsung sangat bagus. Menurut observer 1, masih ada 1 langkah yang belum dilakukan guru. Tetapi menurut observer 2 dan 3 menyatakan pembelajaran sudah berlangsung baik sesuai dengan langkah-langkah pembelajaran yang sudah direncanakan.

2) Pertemuan kedua

Secara umum sudah sesuai dengan rencana tindakan (RPP Pertemuan II). Berdasarkan observasi dan hasil analisis data diketahui bahwa pembelajaran sudah baik. Menurut observer 1 dan 2 pembelajaran dinyatakan sudah sesuai dengan langkah-langkah tang direncanakan. Sedangkan observer 3 memberikan catatan, perlunya anak diberikan reward yang sesuai ketika anak dapat mengerjakan tugas dengan baik. 
3) Pertemuan ketiga

Sebagaimana pada pertemuan 1 dan 2, pertemuan ke 3 sudah sesuai rencana (sesuai RPP). Berdasar observasi dan analisis data diketahui bahwa pembelajaran sudah berlangsung sangat baik. Menurut observer a, 2, dan 3 pembelajaran sudah baik, hanya perlu lebih memberi motivasi pada anak, sehingga anak lebih bersemangat.

Hasil Penelitian Siklus, dilihat dari rata-rata kelas, siklus 2 telah mengalami kenaikan dari 72,1 menjadi 83, 16. Dilihat dari materi, untuk materi PPKn relatif mudah pada KD 3.2 dan 4.2 dari KD sebelumnya. Bila dikategorikan yang sudah tuntas dan belum tuntas sebagai berikut: Presentase belum tuntas : $3 / 30 \times 100 \%=10 \%$ Presentase sudah tuntas : $27 / 30 \times 100 \%=90 \%$

Tabel 4.3.

Hasil belajar kondisi awal, siklus 1 dan 2

\begin{tabular}{|l|l|l|l|l|}
\hline \hline No. & Kategori Nilai & Kondisi Awal & Siklus 1 & Siklus 2 \\
\hline 1. & $\begin{array}{l}\text { Belum Tuntas } \\
(<\mathrm{KKM})\end{array}$ & $73 \%$ & $46,66 \%$ & $10 \%$ \\
\hline 2. & Tuntas $(\geq \mathrm{KM})$ & $27 \%$ & $53,34 \%$ & $90 \%$ \\
\hline
\end{tabular}

Dari tabel $\mathrm{d}$ atas menunjukkan bahwa hasil belajar siswa mengalami peningkatan setelah dilakukan tindakan. Presentase siswa yang belum tuntas mengalami penurunan dari siklus 1 ada 46,66\% menjadi $10 \%$ pada siklus 2. Presentase siswa yang sudah tuntas mengalami kenaikan dari 53,34\% pada siklus 1 naik menjadi $90 \%$ pada siklus 2.

Indikator keberhasilan PTK adalah, PTK ini dikatakan berhasil jika presentase siswa yang nilai hasil belajarnya sudah tuntas mencapai minimal 80\%, maka PTK sudah berhasil (tidak dilanjutkan pada siklus 2

\section{c. Proses pembelajaran}

Dari tiga observer menunjukkan bahwa pembelajaran secara umum sudh baik. Menurut observer 1 dan 2 pembelajaran sudah sangat baik, namun pada observer 3 memberi catatan perlunya pemberian motivasi yang lebih sehingga siswa lebih bersemangat.

\section{Refleksi Siklus 2}

Dari analisa data hasil belajar siswa menunjukkan dari kondisi awal, ke siklus 1 dan siklus 2 mengalami peningkatan yang cukup berarti. Presentase hasil belajar pada siklus 2 sudah mencapai target (Indikator kinerja). 
Dari analisa data menunjukkan proses pembelajaran yang dilakukan pada siklus 2 jauh lebih baik dibanding pada siklus 1 . Secara umum proses pembelajaran pada siklus 2 kategorinya sangat baik. Dari data-data tersebut menunjukkan bahwa tindakan yang dilakukan oleh guru (peneliti) terus mengalami perbaikan dan sudah mencapai sesuai yang ditargetkan. Maka siklus PTK ini selesai pada siklus 2 saja.

\section{PEMBAHASAN}

Hasil belajar sangat ditentukan oleh proses pembelajaran. Proses pembelajaran yang monoton, tidak akan berdampak pada keberhasilan siswa dalam mencapai hasil belajar yang optimal. Peningkatan hasil belajar bisa ditingkatkan ketika proses pembelajaran yang berlangsung melibatkan siswa dalam berbagai bentuk dan langkah kegiatan. Metode proyek based learning merupakan salah satu model pembelajaran yang melibatkan semua potensi siswa sehingga pembelajaran abad 21 yang memperhatikan 4 kemampuan (creative, comunication, colaborative, critis) dapat dicapai.

Tahap-tahap belajar problem based learning menunjukkan proses pembelajaran yang bervariasi. Secara umum langkah-langkah tersebut dapat memberikan dampak terhadap peningkatan hasil belajar siswa. Tetapi, hasil penelitian ini menunjukkan bahwa setiap langkah model pembelajaran problem based learning harus dilakukan lebih kreatif dan inovatif. Guru memiliki peran dalam merancang pembelajarn agar lebih kreatif dan menarik. Dalam langkahlangkah pembelajaran proyek based learning dapat dilihat sebagai berikut:

\section{Siklus Pertama}

Pada siklus ini guru telah menerapkan langkah-langkah mdel problem based learning sesuai dengan prosedur. Tetapi pada pelaksanaannya belum optimal karena ada beberapa langkah yang dilakukan memerlukan kreatifitas dan inovasi, yakni (a) Guru belum sepenuhnya mengorganisir siswa, siswa hanya membuat kelompok sendiri sehingga kemampuan kelompok. (b) Guru belum memberikan penilaian pada persiapan siswa ketika akan presentasi, sehingga penampilan siswa kurang maksimal. (c) Guru belum mengelompokkan siswa dengan merata, Sehingga ada kelompok aktif sekali tetapi ada kelompok yang pasif, sehingga pembelajaran kurang hidup. Namun secara umum, pada siklus ini hasil belajar lebih baik dibanding kondisi awal.

Setelah dilakukan diskusi refleksi, kekurangan-kekurangan tersebut diperbaiki yaitu dengan (1) Guru (peneliti) harus bisa mengembangkan variasi pembelajaran, baik dalam metode, alat pembelajaran, maupun dalam penyampaian. Sehingga anak tidak jenuh. (2) Guru harus menggunakan berbagai model dalam pembentukan kelompok, sehingga siswa akan bisa berkomunikasi dengan teman-teman yang lain. Hal itu untuk menumbuhkan komunikasi dan kolaborasi yang baik antar teman. (3) Guru (peneliti) harus lebih memberikan motivasi dan semangat kepada anak didik, baik itu berupa pujian, kalimat yang menggugah semangat maupun kegiatan yang bisa 
menggerakkan motivasi anak dalam belajar. (4) Guru (peneliti) secara umum harus mengoptimalkan siswa agar mendapatkan nilai yang lebih baik. Dari catatan tersebut, lalu guru (peneliti) melakukan perbaikan-perbaikan guna pembelajaran yang ebih baik.

\section{Siklus Kedua}

Dari analisis data hasil belajar siswa menunjukkan mengalami penngkatan dari kondisi awal, ke siklus 1 dan siklus 2. Presentase hasil belajar pada siklus 2 sudah mencapai di atas target yang ditetapkan. Data ini menunjukkan bahwa proses pembelajaran yang dilakukan oleh guru (peneliti) memberikan dampak bagi peningkatan hasil belajar siswa. Untuk lebih jelasnya dapat dilihat pada tabel dan grafik berikut ini:

Tabel 4.4.

Hasil belajar kondisi awal, siklus 1 dan 2

\begin{tabular}{|l|l|l|l|l|}
\hline \hline No. & Kategori Nilai & Kondisi Awal & Siklus 1 & Siklus 2 \\
\hline 1. & $\begin{array}{l}\text { Belum Tuntas } \\
(<\mathrm{KKM})\end{array}$ & $73 \%$ & $46,66 \%$ & $10 \%$ \\
\hline 2. & Tuntas $(\geq \mathrm{KM})$ & $27 \%$ & $53,34 \%$ & $90 \%$ \\
\hline
\end{tabular}

Grafik 4.1.

Hasil belajar kondisi awal, siklus 1 dan siklus 2

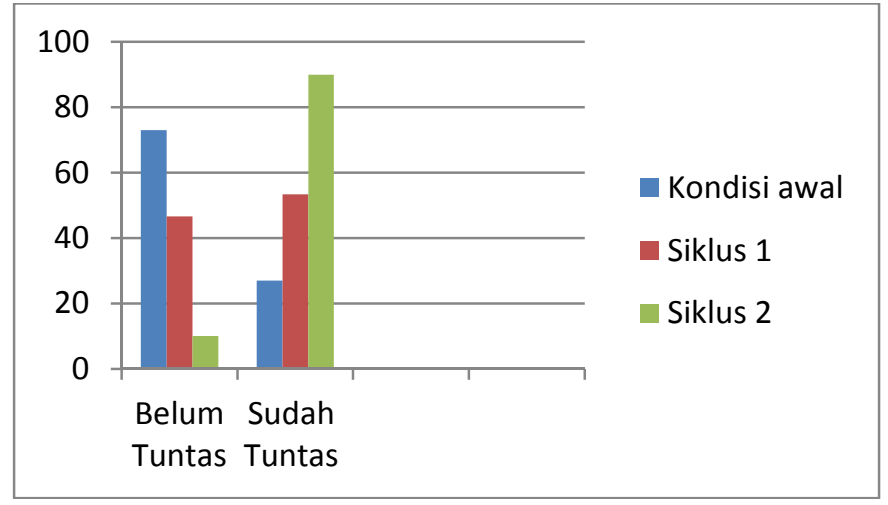

Dari analisa data menunjukkan proses pembelajaran yang dilakukan pada siklus 2 jauh lebih baik dibanding pada siklus 1 . Secara umum proses pembelajaran pada siklus 2 kategorinya sangat bagus. Dari data-data tersebut menunjukkan bahwa tindakan yang dilakukan oleh guru (peneliti) terus mengalami perbaikan dan sudah mencapai sesuai yang ditargetkan. Maka siklus PTK ini selesai pada siklus 2 saja. 
CIVICS EDUCATION AND SOCIAL SCIENSE JOURNAL(CESSJ)

Volume 2 Nomor 2 Edisi Bulan Desember 2020

\section{SIMPULAN}

Hasil penelitian dengan judul "Peningkatan Hasil Belajar Siswa Kelas Vb MIN 2 Bantul pada materi hak dan kewajiban sebagai warga Negara Semesrter II Tahun Pelajaran 2019/2020 Menggunakan Model Proyek Based Learning" dapat disimpulkan sebagai berikut:

1. Penelitian menunjukkan bahwa terjadi peningkatan prestasi belajar materi hak dan kewajiban sebagai warga negara pada Siswa Kelas Vb MIN 2 Bantul. Sebelum dilaksanakna penelitian, diadakan evaluasi pada materi hak dan kewajiban warga negara, sebagai studi pendahuluan. Dari hasil evaluasi pendahuluan diperoleh nilai rata-rata kelas 72,22 atau $27 \%$ siswa telah memenuhi KKM yang ditetapkan. KKM yang ditetapkan adalah 75,00.

2. Hasil evaluasi pelaksanaan pembelajaran pada siklus 1, nilai rata-rata siswa mencapai 72,1. Dari 30 siswa, 16 siswa telah memenuhi KKM dan prosentasenya 53,34 \%. Adapun yang belum memenuhi KKM ada 14 anak dan prosentasenya 46,66 \%. Hasil evaluasi pada pelaksanaan pembelajaran siklus II, nilai rata-rata siswa mencapai 83,33. Dari 30 siswa 27 siswa telah memenuhi KKM dan prosentasenya $90 \%$, adapun siswa yang belum memenuhi KKM sebanyak 3 dan prosentasenya $10 \%$. Target keberhasilan pembelajaran kelas adalah nilai rata-rata 75,00 dan sudah memenuhi KKM $80 \%$. Berarti bisa dikatakan keberhasilan penelitian telah tercapai.

\section{REFERENSI}

Drajat. 2020. Cara Mudah Membuat Penelitian Tindakan Kelas. Solok: LPP Balai Insan Cendekia.

Fathurrohman, Muhammad. 2015. Model-Model Pembelajaran Inovatif. Yogyakarta: Ar-Ruzz Media

Ibnu Badar Al-Tabany, Trianto. 2014. Mendesain Model Pembelajaran Inovatif,

Komalasari, Kokom. 2013. Pembelajaran kontekstual. Cetakan ketiga. Bandung: PT. Refika Aditama.

Majelis Permusyawaratan Rakyat Republik Indonesia. 2012. Undang-Undang Dasar Negara Republik Indonesia Tahun 1945. Jakarta: Sekretaris Jenderal MPR RI.

Priansa, Donni Juni. 2015. Manajemen Peserta Didik dan Model Pembelajaran. Cetakan Kesatu. Bandung: Penerbit Alfabeta.

Priansa, Donni Juni. 2017. Pengembangan Strategi dan Model Pembelajaran. Cetakan Kesatu. Bandung: Penerbit Pustaka Setia 
CIVICS EDUCATION AND SOCIAL SCIENSE JOURNAL(CESSJ)

Volume 2 Nomor 2 Edisi Bulan Desember 2020

Progresif, dan Kontekstual. Jakarta: Prenadamedia Group.

Purwanto. 2016. Evaluasi Hasil Belajar. Yogyakarta: Pustaka Pelajar.

Tim Penyusun Kamus Pusat Pembinaan dan Pengembangan Bahasa. 1995. Kamus Besar Bahasa Indonesia. Edisi Kedua. Jakarta: Balai Pustaka

Widodo, Wahyu.Anwari Budi. Maryanto. 2015. Pendidikan Kewarganegaraan. Yogyakarta: Andi Offset 